Article

\title{
Disentangling How Populism and Radical Host Ideologies Shape Citizens' Conceptions of Democratic Decision-Making
}

\author{
Reinhard Heinisch and Carsten Wegscheider * \\ carsten.wegscheider@sbg.ac.at (C.W.) \\ * Corresponding author \\ Submitted: 14 February 2020 | Accepted: 18 May 2020 | Published: 17 July 2020
}

Department of Political Science, University of Salzburg, 5020 Salzburg, Austria; E-Mails: reinhard.heinisch@sbg.ac.at (R.H.),

\begin{abstract}
In this article, we aim to disentangle the extent to which citizens' conceptions of democratic decision-making are shaped by populist attitudes or rather by radical left and right host ideologies. Following recent work by Landwehr and Steiner (2017), we distinguish four modes of decision-making embedded in different conceptions of democracy: trusteeship democracy, anti-pluralism, deliberative proceduralism, and majoritarianism. Drawing on data from Austria and Germany, we show that populism and radical host ideologies tap into different dimensions of democracy. While populism is primarily directed against representative forms of democratic decision-making, preferences for deliberative procedures and majority decisions appear entirely shaped by radical left and right host ideologies. Populism thus views decision-making based on the general will of the people as the only legitimate democratic procedure, whereas radical left and right host ideologies aim at involving the relevant group(s) of citizens. Further analyses of the interactions between populist attitudes and radical host ideologies confirm that the effects of populism remain robust and thus independent of the specific manifestations of radical host ideologies. These findings help to disentangle the causes of democratic discontent and to develop possible responses through democratic reforms that specifically and separately aim to mitigate populism and radical host ideologies.
\end{abstract}

\section{Keywords}

Austria; democratic decision-making; democracy; Germany; host ideology; populism; populist attitudes

\section{Issue}

This article is part of the issue "Populism and Polarization: A Dual Threat to Europe's Liberal Democracies?" edited by Jonas Linde (University of Bergen, Norway), Marlene Mauk (GESIS - Leibniz Institute for the Social Sciences, Germany) and Heidi Schulze (GESIS-Leibniz Institute for the Social Sciences, Germany).

(C) 2020 by the authors; licensee Cogitatio (Lisbon, Portugal). This article is licensed under a Creative Commons Attribution 4.0 International License (CC BY).

\section{Introduction}

The conceptions of democracy underlying the ideology of radical populist parties arguably pose a threat to both liberal and representative democracy (Galston, 2018; Pappas, 2019; Plattner, 2010; Taggart, 2004; Urbinati, 1998). Yet, we know little about how the attitudes pertaining to the populist core on the one hand and those based on radical left or right host ideologies on the other relate to normative conceptions and expectations about democratic decision-making. Following an ideational approach (Hawkins, Carlin, Littvay, \& Rovira Kaltwasser,
2018; Mudde \& Rovira Kaltwasser, 2017), we view populism as directed against the liberal principles of democracy such as minority rights and the rule of law, while favoring direct popular participation rather than decisionmaking by elected representatives. Radical left and right host ideologies, by contrast, define manifestations of social grievances in society, assign blame to those they label responsible, and propose different solutions in the form of radical change in favor of those who ought to govern in the place of corrupt politicians.

The challenge is that populism rarely occurs alone, but often in tandem with a radical left or right host ide- 
ology. This entanglement has given rise to a considerable debate on the precise locus of the effect. Specifically, whether effects can be independently ascribed and thus measured, or whether they are inherently intertwined, even to the point that populism per se is an empty shell. Proceeding from the idea that populism has a substantial core and is meaningfully distinct from the influence of host ideologies, our analysis will need to show that the effects are independently present in the dependent variables. In this article, we therefore aim to disentangle this relationship by examining the extent to which citizens' conceptions of democratic decision-making are shaped by populist attitudes or rather by attitudes towards radical left and right host ideologies. Accordingly, we ask to what extent populist attitudes and attitudes based on radical left and right host ideologies affect citizens' conceptions of democratic decision-making.

Drawing on recent research by Landwehr and Steiner (2017) on the gap between democratic aspirations and democratic practice, we distinguish four modes of democratic decision-making embedded in different conceptions of democracy: trusteeship democracy, antipluralism, deliberative proceduralism, and majoritarianism. Using data from the GESIS Panel (Bosnjak et al., 2018; GESIS, 2019) for Germany and the Austrian National Election Study (AUTNES) Online Panel (Wagner et al., 2018), we focus on the distinction between populism and radical host ideologies and their impact on citizens' understanding of the functional and procedural aspects of democracy.

Our article proceeds by first laying out our theoretical argument and discussing the relationship between populism and radical host ideologies as related to different conceptions of democratic decision-making. After stating our hypotheses, we present the research design and briefly introduce our two cases, Austria and Germany. This is followed by the empirical analysis and the discussion of our findings.

\section{Theoretical Argument}

\subsection{Citizens' Conceptions of Democratic Decision-Making}

In recent years, scholars have increasingly focused on citizens' preferences for democracy and specific decisionmaking procedures (Bengtsson, 2012; Bengtsson \& Mattila, 2009; Bowler, Donovan, \& Karp, 2007; Font, Wojcieszak, \& Navarro, 2015; Hibbing \& Theiss-Morse, 2001). Overall, research has shown that certain attitudes towards the democratic decision-making process affect citizens' participation in politics (Bengtsson \& Christensen, 2016; Gherghina \& Geissel, 2017; Neblo, Esterling, Kennedy, Lazer, \& Sokhey, 2010; Webb, 2013). Moreover, citizens' conceptions of democratic decisionmaking constitute the individual yardstick for evaluating the functioning of democracy in practice (Landwehr \& Steiner, 2017). Democratic discontent is thus also rooted in how citizens define democracy and their expectations of the way democratic decisions should be taken.

In turn, democratic discontent, alongside ideological attitudes and policy preferences, is an important explanation for the success of radical populist parties over time and across countries (Hernández, 2018; Lubbers, Gijsberts, \& Scheepers, 2002; Rooduijn, 2018; Schumacher \& Rooduijn, 2013). Apart from these presumed indirect effects, recent studies show that certain notions of democracy are also directly related to the support for populist (radical right) parties (Schmitt-Beck, van Deth, \& Staudt, 2017; Steiner \& Landwehr, 2018). In order to explain the success of radical populist parties, it is therefore essential to disentangle the relationships between populism, radical host ideologies and different conceptions of democratic decision-making.

Following previous research by Landwehr and Steiner (2017), we distinguish between a core concept of democracy as a first layer and conceptions of democratic decision-making as a second layer. While the first layer refers to the essential guidelines and regime principles of democracy, the second layer deals with the norms and procedures of how democratic decisions should be made (Dalton, 2004; Easton, 1965). Since populist citizensthose holding populist attitudes-support democracy over other forms of government, while being dissatisfied with the way democracy works in practice (Rovira Kaltwasser \& Van Hauwaert, 2020; Vehrkamp \& Wratil, 2017), we assume that this dissatisfaction is not per se the result of a general rejection of democratic principles but based on specific normative expectations of the democratic decision-making process.

In accordance with Landwehr and Steiner (2017), we distinguish four modes of democratic decisionmaking embedded in different conceptions of democracy: trusteeship democracy, anti-pluralism, deliberative proceduralism, and majoritarianism. These conceptions broadly represent four distinct ideas about how democracy should be constituted normatively and functionally, and which are crucial to the current debate about democratic development. Trusteeship democracy refers to the common type of representative democracy in which legislators act as trustees of their voters. While this mode of decision-making requires trust on the part of the voter that the representative has the best interest of the citizens in mind, it also entails searching for compromises away from the spotlight and public opinion. The anti-pluralist mode views conflict between different particularistic interests as detrimental to the general welfare of the people. Accordingly, important political decisions are rather to be left to experts. Deliberative proceduralism here refers to decision-making through procedures in which the concern for general welfare outweighs individual and particularistic interests. The mode of majoritarianism is based on the idea that the government should respond primarily to a common will of the (relevant) people. Incorporating minorities and diverse views is seen as tantamount to thwarting the will of the people. 


\subsection{How Populism Relates to Democratic Decision-Making}

Following an ideational approach (Hawkins et al., 2018; Mudde \& Rovira Kaltwasser, 2017), we define populism as a thin-centered "ideology that considers society to be ultimately separated into two homogeneous and antagonistic groups, 'the pure people' versus 'the corrupt elite,' and which argues that politics should be an expression of the volonté générale (general will) of the people" (Mudde, 2004, p. 543). On the part of voters, populism exists as a set of widespread attitudes among ordinary citizens that lie dormant until activated by weak democratic governance and policy failure. These attitudes are centered on the three constituent ideational elements of anti-elitism, people-centrism, and a Manichean worldview (Akkerman, Mudde, \& Zaslove, 2014; Castanho Silva, Jungkunz, Helbling, \& Littvay, 2019; Rooduijn, 2014).

The ambivalent nature of the relationship between populism and democracy remains essentially controversial and has been the subject of claims and counterclaims. Some scholars suggest that populists may force incumbent traditional parties to become more attentive, thereby mitigating a growing crisis of representation (Kriesi, 2014; Mair, 2002; Taggart, 2002), but have otherwise little measurable negative impact on the political system (Canovan, 1999; Heinisch, 2003; Mény \& Surel, 2002; Mudde \& Rovira Kaltwasser, 2012; Rovira Kaltwasser, 2014). Others have pushed back against this perspective by arguing that while populism is not anti-democratic per se, its antagonism to the procedural aspects of liberal representative democracy is wellestablished (Galston, 2018; Heinisch \& Wegscheider, 2019; Huber \& Schimpf, 2016, 2017a, 2017b; Pappas, 2019; Plattner, 2010; Taggart, 2004; Urbinati, 1998).

This is because the people are seen as the "ultimate source of legitimacy" (van Kessel, 2015, p. 15) for democracy and, thus, the popular will is above criticism and beyond institutional constraints. Accordingly, radical populists in advanced Western European democracies regard the people as betrayed not simply by the personal corruption of elites but by systematic programmatic misrepresentation (Mudde, 2004). As a consequence, populists frequently call for the direct implementation of the people's will through plebiscitary measures (Abts \& Rummens, 2007; Barr, 2009; Canovan, 2002). Likewise, political divisions are not seen as legitimate differences of interest but rather the result of outsider meddling. As a result, compromises designed to resolve such differences are often regarded as less than fully legitimate (Schedler, 1996). By rejecting the idea of a plurality of positions and interests and by presenting political decision-making in the form of stark moral choices between good and evil (Mudde, 2004; Plattner, 2010), democratic decisions are framed as between those for and against the people. Such a binary moral framework may intensify already bifurcated attitudes towards how democratic procedures work.
Procedurally speaking, populism assigns a central role to the people in decision-making, thus supporting participatory approaches to democracy in the form of plebiscites (Mohrenberg, Huber, \& Freyburg, 2019). Populists also prefer a passive role in politics (stealth democracy), assuming that the government is responsive and implements policies according to their interests (Stoker \& Hay, 2017). This, in turn, makes deliberation in politics seemingly superfluous in populists' eyes as long as political outcomes are in line with the general will (Urbinati, 2019). On a more general level, populists are likely to oppose representative democracy, characterized by a plurality of preferences, mediation, and compromises and thus political decision-makers acting as trustees on behalf of diverse citizens interests (Taggart, 2000, 2004). Nonetheless, populists may prefer experts to policy-makers because the former are less likely to be regarded as self-serving (Mohrenberg et al., 2019).

Based on our discussion of the relationship between democracy and populism, we assume the following effects of populist attitudes on democratic decisionmaking: We expect to see attitudes that elites and representatives are untrustworthy and resented for making all the important decisions, while ordinary people are seen as being ignored and powerless. Decision-making processes are likely regarded as opaque and potentially corrupt so that the compromises achieved are not representative of the genuine popular will. In short, following the populist core framework, the procedural dimension of current liberal representative democracy is likely to be viewed negatively because the decision-makers are self-serving; the people for whom the decisions are to be made are not adequately represented; and the process of reaching a decision is tainted. In the following, we provide specific explanations for our hypotheses and show how the above discussion applies.

The first hypothesis posits that the very anti-elitism and people-centrism inherent in populism will cause such citizens to be skeptical towards elected politicians and, thus, evaluate the principles of representation negatively. As a result, we state it as follows:

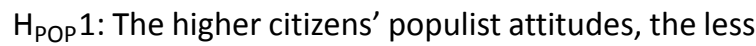
they support trusteeship democracy.

The next hypothesis concerns the populist notion of the people as being unified and homogeneous. This runs counter to pluralism, which implies diversity of opinion, thus bestowing legitimacy to non-majoritarian viewpoints. In consequence, populism perceives such decision-making modes as illegitimate or a threat. Therefore, we specify the following hypothesis:

$\mathrm{H}_{\mathrm{POP}}$ 2: The higher citizens' populist attitudes, the more they support anti-pluralism.

When it comes to populist attitudes and support for deliberative democracy, we theorize that populists will see 
little need for such a process if governments enact the popular will. Any mediation beyond that would, in their view, only invite illegitimate extraneous influences into the mix. However, if the original decision had not come about based on the popular will, then, accordingly, no deliberative mechanisms would restore legitimacy. Hence, we state the hypothesis as follows:

$\mathrm{H}_{\mathrm{POP}} 3$ : The higher citizens' populist attitudes, the less they support deliberative proceduralism.

Concerning the relationship between populism and majoritarianism, we note that the central idea in populism is that legitimate decisions derive from the unmediated majority opinion of the people as they are the source of political power. Thus, our hypothesis reads as follows:

$\mathrm{H}_{\text {POP }}$ : The higher citizens' populist attitudes, the more they support majoritarianism.

\subsection{How Radical Host Ideologies Relate to Democratic Decision-Making}

In this section, we lay out our argument for how radical host ideologies affect the four conceptions of democratic decision-making and proceed from the assumption that populism is a thin ideology and thus attached to different radical host ideologies (Stanley, 2008; Taggart, 2000). In keeping with the ideational approach and mindful of arguments to the contrary, we conceive populism as having a substantive core of its own with distinct influences, independent of the radical right or left host ideology with which populism is associated. In trying to determine the extent to which the effect on attitudes towards democratic decision-making is based on the radical host ideology, we first need to establish its plausible connection with the respective procedural modes. Only then, in a further step, we will be able to see whether the interactions between host ideologies and populism manifest any combined effects. Thus, our subsequent discussion specifies the causal connection between the dependent variables and radical host ideologies independent of populism.

The radical right ideology is based on the characteristics of nativism and right-wing authoritarianism (Mudde, 2007). The ideological core of the radical right is a combination of an exclusive nationalism and xenophobia (Rydgren, 2007, 2018). This nativist worldview "holds that states should be inhabited exclusively by members of the native group ('the nation') and that nonnative elements (persons and ideas) are fundamentally threatening to the homogeneous nation-state" (Mudde, 2007 , p. 19). The second characteristic of the radical right ideology is right-wing authoritarianism and encompasses the characteristics of authoritarian submission, authoritarian aggression, and conventionalism (Adorno, Frenkel-Brunswik, Levinson, \& Sanford, 1950; Altemeyer, 1981). Right-wing authoritarianism is the belief in a strictly ordered hierarchical society demanding submis- sion to authority and social conventions (Mudde, 2007; Rydgren, 2018) and is due to an "uncritical, respectful, obedient support for existing societal authorities and institutions" (Duckitt \& Bizumic, 2013, p. 843).

Drawing on these two components of the radical right ideology, we formulate our hypotheses regarding the relationship to the four conceptions of democratic decision-making, albeit following a different causal inference. In the case of the radical right, the cause is not antielitism and the general will but rather a specific concern about compromises with and the influence of (a) those who are ethnically not part of the autochthonous people (nativism) and (b) those subverting existing authority structures (right-wing authoritarianism). Although these hypotheses are pointing in the same direction as those stated above, we expect the relative effects to be different. The subsequent segment provides specific explanations for our hypotheses and shows how our above discussion applies.

The first hypothesis is based on the argument that as long as representation cannot be effectively restricted to the acceptable autochthonous populations, political trusteeship remains unacceptable to radical right citizens because it would potentially lead to outcomes that reflect the political input of socio-cultural others. Incidentally, this is different from populists whose insistence on anti-elitism and people-centeredness calls the principle of representation itself into question. Nativists, by contrast, should have no objection in principle to being represented by other nativists. Additionally, obedience and submission to societal authorities and conventions inherent in right-wing authoritarianism might lead to a positive evaluation of institutionalized hierarchies of representation. While this relationship is ambiguous and far from clear, given the aversion of the radical right towards politicians acting as trustees of socio-cultural others, we assume a negative relationship between radical right attitudes and representative decision-making. Thus, we state the hypothesis as follows:

$H_{R R} 1$ : The higher citizens' radical right attitudes, the less they support trusteeship democracy.

As in the previous case, any form of pluralism entails recognizing the legitimate interests of socio-cultural others, which nativists would have to reject if they wanted to see their own interests prevail. Given the ideological opposition between radical right positions and pluralism, we formulate our hypothesis as follows:

$\mathrm{H}_{\mathrm{RR}}$ 2: The higher citizens' radical right attitudes, the more they support anti-pluralism.

We also expect radical right attitudes to have a negative effect on supporting deliberative proceduralism because a feature of the radical right ideology is the belief in vertical authority. Once a legitimate and acceptable leader is selected, it is unlikely that there would be support for 
a grassroots process designed to undermine or upend the authority of that leader. Hence, our hypothesis reads as follows:

$\mathrm{H}_{\mathrm{RR}} 3$ : The higher citizens' radical right attitudes, the less they support deliberative proceduralism.

Given that autochthonous populations form a majority in most democracies, majoritarian processes dilute the resented influence of socio-cultural or socio-political minorities. Thus, nativists are expected to support majoritarianism. Here it is less the principle of peoplecenteredness but rather the potential to preserve the substantive nativist agenda that matters. We state our hypothesis as follows:

$\mathrm{H}_{\mathrm{RR}} 4$ : The higher citizens' radical right attitudes, the more they support majoritarianism.

While the radical right focuses on an authoritarian and nativist stance, the radical left mobilizes mainly based on socio-economic grievances and offers leftist policy solutions (March, 2017). The radical left ideology is focused on the exploitation of societies due to the "socioeconomic structure of contemporary capitalism" (March \& Mudde, 2005, p. 25) and thus rejects its values and practices. Radical left parties promote alternative redistribution policies and a strong role of the state in the economy to combat social and economic inequalities (March, 2007, 2011). Alongside these economic positions, radical left parties often represent 'new left' issues such as gender equality, gay rights and other egalitarian policies (Rooduijn \& Akkerman, 2017; Stavrakakis \& Katsambekis, 2014). As such, we expect different effects on democratic decision-making modes. In particular, we assume it to be more favorably disposed towards pluralism and deliberative procedures, as these promise greater social inclusion. At the same time, we would expect greater skepticism towards trusteeship democracy, because it appears more open to behind-scenes lobbying, which tends to favor economic interests. In the following, we specify our hypotheses and provide brief explanations:

Trusteeship democracy allows for a selective and opaque access to political decision-makers. Accordingly, the asymmetrical resource distribution between economic interest groups places lobbies representing capital and business at an advantage causing radical left citizens to be skeptical. Hence, our hypothesis reads as follows:
$H_{R L} 1$ : The higher citizens' radical left attitudes, the less they support trusteeship democracy.

When it comes to anti-pluralism, we assume that radical left citizens not only represent diverse interests whose input matters to them but they are also conscious of the greater capacity of business interests to shape public opinion and thus, in their eyes, manufacture majorities. Pluralism provides for a way to mitigate this disadvantage and thus we hypothesize:

$\mathrm{H}_{\mathrm{RL}}$ 2: The higher citizens' radical left attitudes, the less they support anti-pluralism.

To the extent that leftist populists view major political decisions to reflect the interests of the economically powerful, a deliberative procedure is seen as another opportunity to increase citizen input and thus viewed favorably. Accordingly, we state our hypothesis as follows:

$\mathrm{H}_{\mathrm{RL}}$ 3: The higher citizens' radical left attitudes, the more they support deliberative proceduralism.

As the radical left tends to represent minority interests, we would expect such citizens to oppose procedures that preclude them from exercising influence. As also shown in the summary of hypotheses in Table 1, we state this hypothesis as follows:

$\mathrm{H}_{\mathrm{RL}} 4$ : The higher citizens' radical left attitudes, the less they support majoritarianism.

\section{Research Design}

\subsection{Data and Case Selection}

We test our hypotheses using survey data from the GESIS Panel (Bosnjak et al., 2018; GESIS, 2019) for Germany and the AUTNES Online Panel (Wagner et al., 2018). Both data are representative samples of the respective population and contain the same questions on citizens' conceptions of democratic decision-making. Moreover, the panel structure of the data enables us to impute missing values of respondents for certain variables from other waves of the data. We normalize all variables within a range from 0 to 1.0 to allow for the comparison of coefficients and simplify the interpretation of our analyses. Tables $A 1$ and $A 2$ in the Supplementary File provide further information on all variables used in our analyses.

Table 1. Summary of hypotheses.

\begin{tabular}{lcccc}
\hline Variable & Trusteeship democracy & Anti-pluralism & Deliberative proceduralism & Majoritarianism \\
\hline Populist attitudes & - & + & - & + \\
Radical right host ideology & - & + & - & + \\
Radical left host ideology & - & - & + & - \\
\hline
\end{tabular}

Notes: The minus sign (-) indicates an expected negative relationship and the plus sign (+) an expected positive relationship. 
Austria and Germany are particularly well suited for comparison to test our hypotheses. A closely related historical legacy as well as similar economic, cultural, and political conditions allow us to keep many factors constant. Yet, based on the approach of institutional socialization, we expect varying perceptions of democracy among citizens from Austria and Germany. These two countries differ in the reappraisal of their National Socialist past and the constitutional definition of democracy. Germany has put in place an explicit commitment to liberal representative democracy as a reaction to its Fascist legacy and is thus a vigorous defender of constitutionalism. Austria, by contrast, has continued an old constitutional approach that separates the normative and political dimension from the procedural, which appears in the constitution as little more than rules of implementation.

Moreover, both countries differ in their post-war experience with radical populist parties in national parliaments. The fact that political parties have significant influence on the articulation and occupation of political issues for the public makes differences between Austria and Germany most likely. While the Austrian Freedom Party (Freiheitliche Partei Österreichs/FPÖ), a highly successful and prototypical populist radical right party, has been in the Austrian parliament since 1956, the corresponding populist radical right party Alternative for Germany (Alternative für Deutschland/AfD) entered the German parliament only in 2017. Furthermore, these two populist radical right parties differ in their political positions. Recent work on the ideological differences has shown the AfD to be far more radical right (also in socio-economic terms) than the FPÖ, which has moderated somewhat and moved more to the left on social and economic issues (Ennser-Jedenastik, 2016; Heinisch \& Werner, 2019; Rovny, 2013). A distinctive feature of the German case is the presence of a relevant populist radical left party, The Left (Die Linke), which has been gradually branching out from its electoral strongholds in Eastern Germany to the rest of the country. As a result of these different experiences with radical populist parties, we also expect differences in the prevalence of populist attitudes and radical left and right host ideologies among Austrian and German citizens. Thus, this case selection and the largely parallel data provide us with confidence as to the robustness and context sensitivity of the findings.

\subsection{Dependent Variables}

Our dependent variables measure citizens' conceptions of democratic decision-making. Following the analysis of Landwehr and Steiner (2017), we distinguish between the four normative conceptions of democratic decision-making outlined above. The original data of the GESIS Panel comprise 18 items on the procedures of democratic decision-making. In the AUTNES Online Panel Study, however, we included only the two variables of each conception of democratic decision-making with the highest factor loadings as analyzed by Landwehr and Steiner (2017, p. 792). Respondents were thus asked to rate eight normative statements on procedures of democratic decision-making on a Likert scale ranging from completely disagree (0) to completely agree (1.0). As shown in Tables B1 and B2 in the Supplementary File, we can confirm the conceptions of democratic decision-making identified by Landwehr and Steiner (2017) with principalcomponent factor analyses. Accordingly, we calculate an additive index for each of the four conceptions of democratic decision-making by adding the values of the two respective variables together. High values on the index of (1) trusteeship democracy mean high levels of trust and support in the mode of representative democracy, while high values on the index of (2) anti-pluralism indicate support for the idea of an anti-particularistic society and acceptance of technocratic ideas of democratic decision-making. High values on the index of (3) deliberative proceduralism mean a high acceptance of democratically made decisions and the prioritization of political decisions that follow the common good. Lastly, high values on the index of (4) majoritarianism indicate support for majority decisions even if they restrict minority rights.

\subsection{Independent Variables}

Our main independent variables are populist attitudes and attitudes towards the radical left and right host ideologies. We measure populist attitudes with an additive index by using a battery of six Likert items, which focus on anti-elitism and popular sovereignty as core concepts of populism (Hobolt, Anduiza, Carkoglu, Lutz, \& Sauger, 2016). Castanho Silva et al. (2019) conclude in their empirical comparison of populist attitudes scales that this scale fails "to capture more than mere anti-elitism" (Castanho Silva et al., 2019, p. 10) and thus does not fully cover the dimensions of the ideational approach to populism (Hawkins et al., 2018; Mudde \& Rovira Kaltwasser, 2017). While we acknowledge this criticism and the resulting limitations in the interpretation of our results, we argue that this scale also captures support for popular sovereignty (Wuttke, Schimpf, \& Schoen, 2020), and we thus believe that, given the limited data available, this scale is at least a defensible approximation to the target concept. High values on this index indicate high populist attitudes (see Table B3 in the Supplementary File).

To measure attitudes towards the radical right host ideology, we use anti-immigration attitudes, as a proxy for nativism, and right-wing authoritarianism. To measure right-wing authoritarianism, we calculate an additive index of five Likert items in Austria (see Table B4 in the Supplementary File) and nine Likert items in Germany (see Table B5 in the Supplementary File), which refer to the three core characteristics of authoritarian submission, authoritarian aggression and conventionalism (Altemeyer, 1981; Duckitt \& Bizumic, 2013). High values mean a high degree of right-wing authoritarian- 
ism. We measure anti-immigration attitudes using an additive index of four Likert items, which capture the rejection of immigrants as a threat to national customs, culture, the economy, and crime (see Table B6 in the Supplementary File). High values indicate a high level of anti-immigration attitudes.

To measure attitudes towards the radical left host ideology, we use preferences for left-wing economic policies. Due to data limitations, we cannot include other important radical left economic attitudes, such as the rejection of capitalism and globalization, as well as cultural attitudes towards 'new left' issues such as gender equality, gay rights and other egalitarian positions. We measure preferences for left-wing economic policies by calculating an additive index using four Likert items (see Table B7 in the Supplementary File) representing support for redistribution, higher state expenditures, combating social and income inequalities, as well as increased state intervention in the economy and labor market. High values mean high support for left-wing economic policies.

\subsection{Control Variables}

As an additional control variable for political ideology, we use the (squared) self-placement on the left-right scale. We further control in all models for political interest as well as for the socio-demographic characteristics of income, education, gender, and age. Due to space constraints, we provide further details on the operationalization in the appendix (Tables $A 1$ and $A 2$ in the Supplementary File). After excluding observations with missing values, our final samples include 1,380 respondents from Austria and 1,807 respondents from Germany. We provide further information such as descriptive statistics (Table A3) and distributions of the dependent (Figures $A 1$ and $A 2$ ) and independent variables (Figures A3, A4, A5 and A6) in the Supplementary File.

\subsection{Estimation Strategy}

As explained in detail in our theoretical argument, we assume that populism and radical host ideologies exert independent effects and constitute separate concepts if the effects caused by populist attitudes remain robust and constant after introducing interactions. Therefore, we apply a two-step approach to investigate whether and to what extent the effects of populist attitudes on citizens' conceptions of democratic decision-making are independent of the effects of radical left and right host ideologies. In a first step, we analyze the independent effects of populist attitudes and those associated with the radical left and right host ideology on the four conceptions of democratic decision-making. In a second step, we include interactions between populist attitudes and the two characteristics of the radical right host ideology (right-wing authoritarianism and anti-immigration attitudes) as well as preferences for left-wing economic policies as a proxy for the radical left host ideology. We thus use the second step of the analyses as an additional robustness test for the independence of the effects of populist attitudes.

\section{Empirical Results}

Figure 1 shows the independent effects of populist attitudes, right-wing authoritarianism, anti-immigration attitudes and preferences for left-wing economic policies on the four conceptions of democratic decision-making for Austria and Germany. Given that we normalize all variables within a range from 0 to 1.0 , the unstandardized coefficients can be interpreted as the maximum shift in the dependent variable due to the change by the independent variable from its minimum to its maximum value. In other words, the unstandardized coefficients show the maximum effect of the independent variable on the dependent variable.

The results of our regression analyses confirm that populist attitudes are negatively related with trusteeship democracy $\left(\mathrm{H}_{\mathrm{POP}} 1\right)$ in both Austria and Germany. The anti-elite orientation inherent in populism leads, as predicted, to a high degree of skepticism among respondents towards elected representatives acting as trustees of their citizens. Thus, our results show that populism's emphasis on the people as the only legitimate political power contradicts representative decisionmaking without considering the (relevant) public opinion. We also note that populist attitudes have by far the strongest effect compared to all other predictors. Thus, a person with high populist attitudes scores about 0.3 to 0.4 points lower in support for trusteeship democracy, which is a remarkably strong effect. Contrary to our expectations, neither attitudes of the radical right $\left(H_{R R} 1\right)$ nor the radical left host ideology $\left(H_{R L} 1\right)$ are systematically associated with higher opposition to representative modes of decision-making. Rather, we find partial evidence that right-wing authoritarianism is associated with higher trust in decision-making by representatives, arguably due to obedience to societal authorities and institutions.

The results also confirm our hypothesis that populist attitudes are positively related with anti-pluralism $\left(\mathrm{H}_{\mathrm{POP}} 2\right)$. Populism's understanding of the people as homogeneous and unified thus leads to the rejection of political debates with particularistic opinions. The populist division of society into good and evil and the exclusion of pluralistic diversity of opinion also refers to parliamentary decision-making by elected politicians, which is better left to independent experts. Again, populist attitudes exert the comparatively strongest effect also on this conception of democratic decision-making. A person with high populist attitudes thus supports anti-pluralism by about 0.4 points more than does a non-populist. In line with our expectations, we also find partial evidence that the radical right host ideology tends to favor antipluralistic decision-making $\left(\mathrm{H}_{\mathrm{RR}} 2\right)$. While the effects of anti-immigration attitudes are almost zero, higher right- 


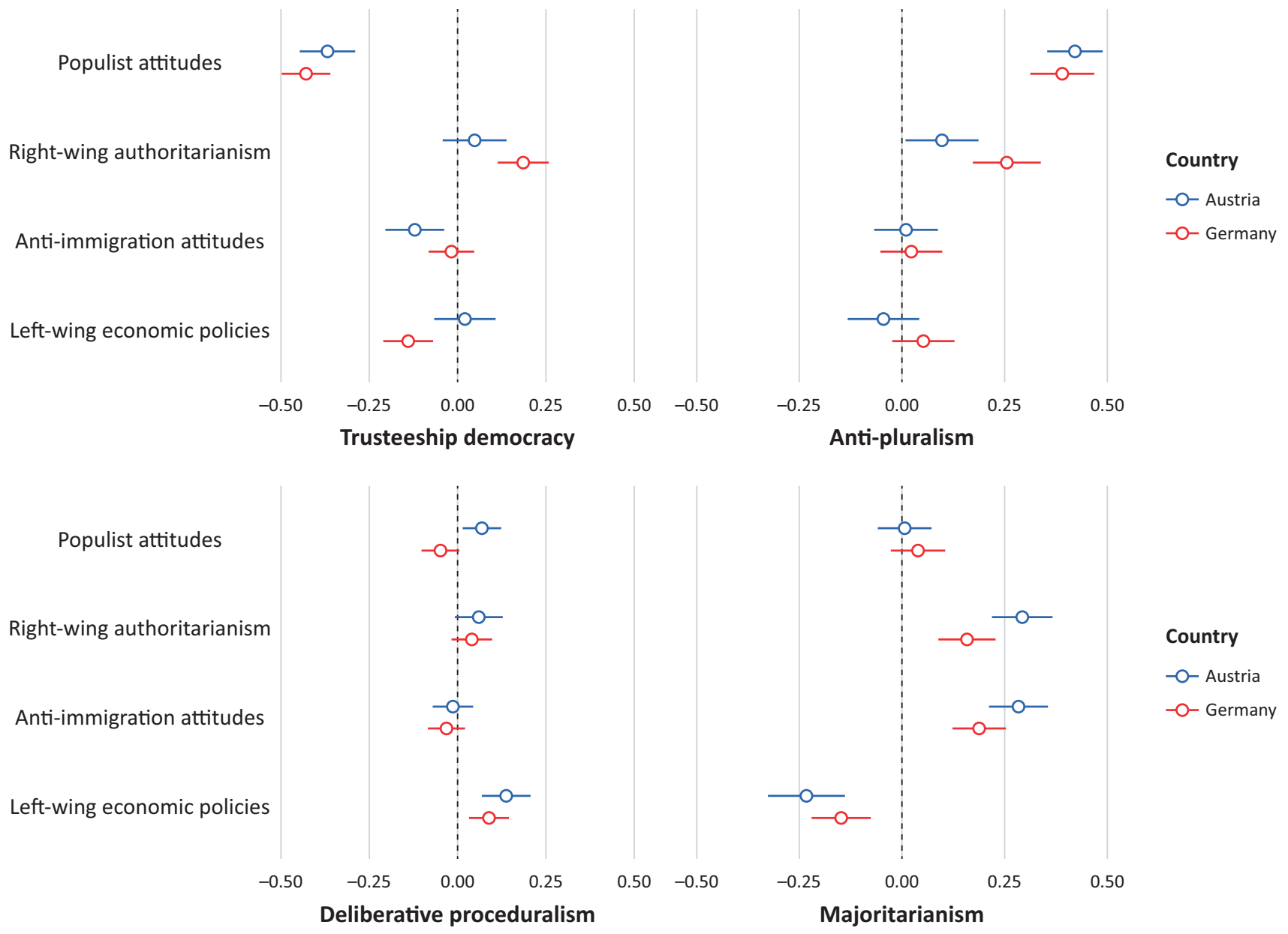

Figure 1. Explaining citizens' conceptions of democratic decision-making. Notes: Plot shows unstandardized coefficients with $95 \%$ confidence intervals and robust standard errors from linear regression models. Full models are reported in Table C1 in the Supplementary File.

wing authoritarianism tends to be associated with higher anti-pluralism. Based on these results, however, we cannot draw any definitive conclusions regarding the association of the radical right host ideology with antipluralism. Regarding the radical left host ideology, we find no systematic negative relationship between the preferences for left-wing economic policies and antipluralism $\left(\mathrm{H}_{\mathrm{RL}} 2\right)$.

While populism is significantly linked to the rejection of representative modes of democratic decision-making, we find, against our expectations, no significant effects of populist attitudes on deliberative proceduralism $\left(\mathrm{H}_{\mathrm{POP}} 3\right)$ and majoritarianism ( $\left.\mathrm{H}_{\mathrm{POP}} 4\right)$. According to our findings, populism is associated neither with a systematic rejection of political decisions reached through deliberation, nor with support for the enforcement of majority decisions that curtail minority rights. Rather, the preferences for these conceptions of democratic decision-making appear entirely shaped by the radical left and radical right ideology.

While we find no significant effects regarding attitudes pertaining to the radical right host ideology $\left(\mathrm{H}_{\mathrm{RR}} 3\right)$, preferences for left-wing economic policies are systematically linked with higher support for democratic decision- making through deliberative procedures $\left(\mathrm{H}_{\mathrm{RL}} 3\right)$. This relationship can be explained by the fact that both leftwing economic policies and deliberative procedures aim to increase the inclusion and participation of underprivileged classes and citizens. However, we also have to note that the effect sizes of all independent variables explaining deliberative proceduralism are comparatively small. Thus, a person with strong preferences for left-wing economic policies supports deliberative proceduralism only between 0.05 and 0.1 points more.

In contrast, radical left and right host ideologies make a clear difference on whether someone is more willing to favor or reject majoritarianism and thus minority rights. While citizens who advocate left-wing economic policies are less inclined to support majoritarianism $\left(\mathrm{H}_{\mathrm{RL}} 4\right)$, those who perceive immigrants as a threat and have an authoritarian personality are more in favor of majority decisions that also curtail minority rights $\left(\mathrm{H}_{\mathrm{RR}} 4\right)$. Accordingly, the inclusion or exclusion of minorities is the most significant difference between the radical left and radical right host ideology. In fact, among all dependent variables, majoritarianism is the dimension of democratic decision-making most shaped by differences between radical host ideologies, which is also reflected in the ef- 
fect sizes. While a person with strong radical right attitudes supports majoritarianism between 0.2 and 0.3 points more, persons with high radical left attitudes support majoritarianism by about 0.2 points less.

After analyzing the independent effects, we examine whether and to what extent the effects of populist attitudes remain robust when combined with a radical host ideology. We follow the idea that if populism does indeed have its own substantive core, the effects should remain constant regardless of the interaction with a radical host ideology. If, in turn, the effect of populist attitudes depends on the strength of nativist or authoritarian attitudes on the one hand, or preferences for leftwing economic policies on the other, populism is indeed highly dependent on its linkage with the radical host ideologies. We therefore use the interactions as a further robustness test to verify that the effects of populism are independent of the radical host ideology with which populism is connected, and that they thus constitute separate concepts.

Figure 2 shows the effects of populist attitudes as well as the interaction effects of populist attitudes depending on the attitudes belonging to radical host ide- ologies on the four conceptions of democratic decisionmaking. Overall, our findings do not indicate a clear and systematic pattern of interaction, suggesting primarily that populism and attitudes pertaining to the radical right and left host ideologies exert independent effects on the support for the different decision-making modes. Only five out of 24 interactions are (slightly) significant, none of them highly significant or systematic for both countries. The few significant interactions show no substantial changes in the effects of populist attitudes. Despite the inclusion of these additional interactions, most of the main effects of our independent variables remain robust under various model specifications. Most importantly, the effects of populist attitudes remain constant, which again suggests that populism follows its own logic regardless of its combination with a radical host ideology.

In order to check the robustness of our results, we have carried out further analyses. While we estimated all interactions in these models simultaneously, we also recalculated all interactions separately. The results for the separate interactions with right-wing authoritarianism (Table C3), anti-immigration attitudes
Populist attitudes

Right-wing authoritarianism $\mathrm{X}$ Populist attitudes

Anti-immigration attitudes $\mathrm{X}$ Populist attitudes

Left-wing economic policies $X$ Populist attitudes

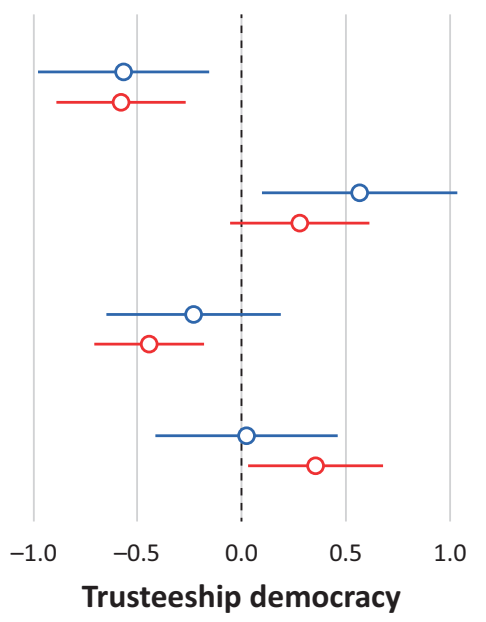

Populist attitudes

Right-wing authoritarianism $\mathrm{X}$ Populist attitudes

Anti-immigration attitudes $X$ Populist attitudes

Left-wing economic policies $X$ Populist attitudes

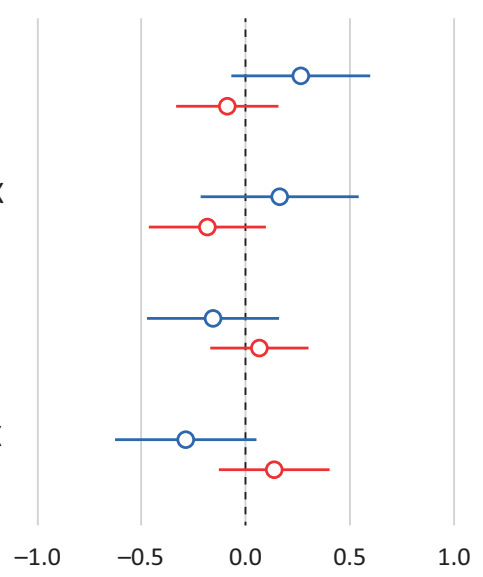

Deliberative proceduralism
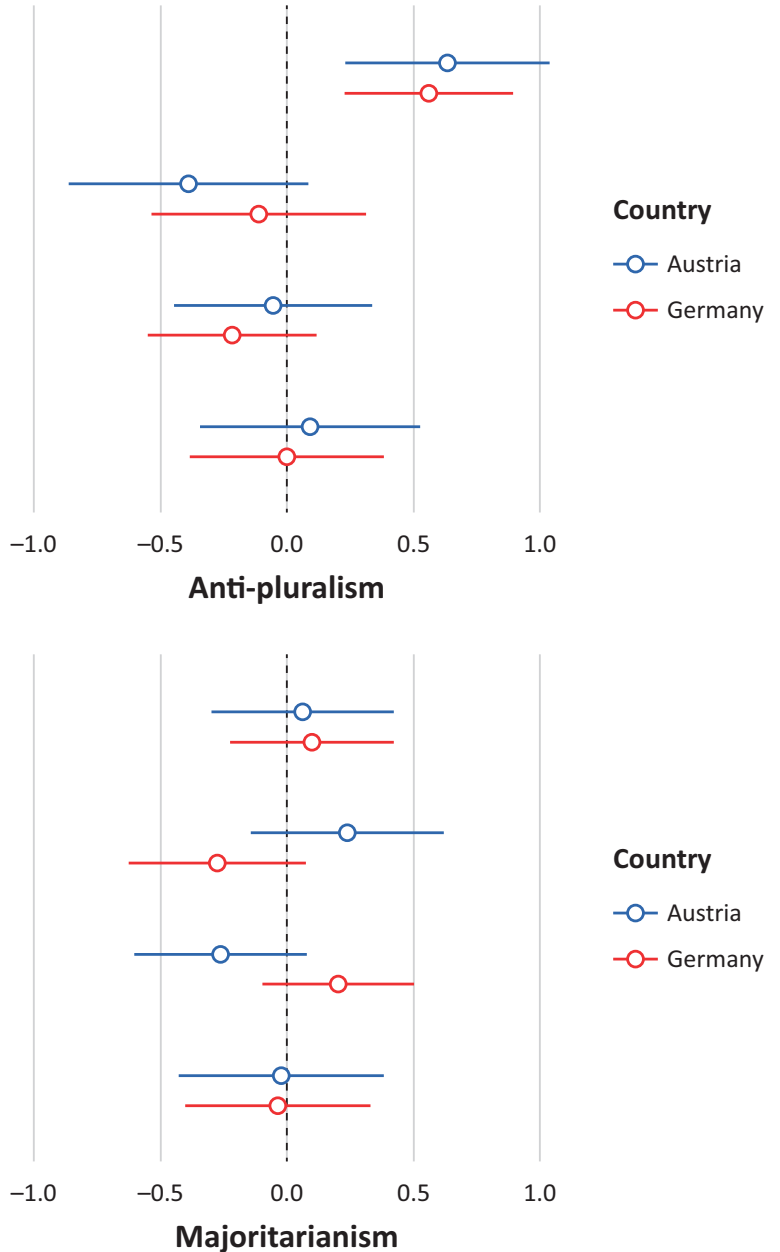

Country

-o- Austria -O- Germany

Figure 2. Explaining citizens' conceptions of democratic decision-making (including all interactions simultaneously). Notes: Plot shows unstandardized coefficients with $95 \%$ confidence intervals and robust standard errors from linear regression models. Full models are reported in Table C2 in the Supplementary File. 
(Table C4), and preferences for left-wing economic policies (Table C5) are shown in the Supplementary File. As a further robustness test, we also performed interactions between populist attitudes and the (squared) selfplacement on the left right scale, as shown in Table C6 in the Supplementary File. Due to similarities between one of the populist attitudes items ("The people, not the politicians, should make the most important political decisions") and one of the items measuring the dependent variable of trusteeship democracy ("Sometimes it is better when complex political decisions are taken by politicians rather than citizens") for the Austrian data, we recalculated all models with the dependent variable of trusteeship democracy without the corresponding populism item. The analyses are presented in Table C7 in the Supplementary File. For all these additional robustness tests, results remain substantially the same. Together with the fact that the results for both countries are very similar despite the differences between Austria and Germany mentioned above, this underscores the robustness of our results.

\section{Conclusion}

In this article, we examined whether citizens' conceptions of democratic decision-making are shaped by populism or attitudes based on the radical right and left host ideologies. Our results show that populism is primarily directed against representative forms of democratic decision-making that supposedly disregard the general will of the people. This is accompanied by a preference for independent experts over elected politicians and the rejection of pluralistic political interests and positions in society and politics. In turn, we find no effect of populism on deliberative decision-making procedures and preferences for majority decisions that disregard minority rights. Rather, these conceptions of democratic decisionmaking appear entirely shaped by the radical left and right host ideologies. While citizens with radical left attitudes are less inclined to support majoritarianism, those with radical right attitudes are more in favor of majority decisions that restrict minority rights. This highlights that, from the perspective of radical host ideologies, democratic decision-making is primarily aimed at involving the relevant group(s) of citizens.

Furthermore, our results show evidence that the effect of populism on conceptions of democratic decisionmaking is independent of specific radical left and right manifestations of host ideologies. Given that the influence of populist attitudes and attitudes towards the radical host ideologies appear to be largely separate from each other, we find little in the way of interaction effects that are consistent for both countries. Furthermore, the selection of the somewhat dissimilar cases of Austria and Germany provides us with a certain robustness and generalizability of our results. While this illustrates that populism and host ideologies are independent and separate concepts, it also highlights the need to examine the ef- fects of populism in light of the ideological attitudes to which populism is connected to avoid under- or overestimating any effects. More importantly, this study underlines the need to design democratic reforms and adopt measures that specifically and separately aim to mitigate populism and radical host ideologies.

Our findings thus have important implications for disentangling the relationship between populism, host ideologies and democracy, and, thus for our understanding of the threat populism poses to liberal and representative democracy. In doing so, we make a genuine contribution to the literature on the demand-side of electoral politics as well as on democratic reforms. Given some methodological limitations, however, we need to point out some potential weaknesses that further research should address. This primarily concerns improved measurements of populist attitudes and attitudes towards radical host ideologies as well as citizens' understanding and their expectations from democratic decision-making.

Further research should also focus more on how populism and attitudes based on radical host ideologies interact and consider possible consequences of these interactions. This refers in particular to possible effects on electoral behavior, and especially on the relevance of citizens' notions of democracy. Based on our findings, further research is needed on the notions of democracy among certain groups of people, e.g., those holding leftwing preferences on economic issues and authoritarian preferences on socio-cultural issues (Lefkofridi, Wagner, \& Willmann, 2014), or those from lower socio-economic strata (Stark, Wegscheider, Brähler, \& Decker, 2017). In addition to a better understanding of democratic discontent, this research can help to promote democratic reforms that ensure the integration and participation of citizens in the political process.

\section{Acknowledgments}

The authors are grateful to Robert Huber, Zoe Lefkofridi, the editors of the journal, the academic editors of this thematic issue, and the two anonymous reviewers for their helpful comments. Carsten Wegscheider presented a first draft of this article at the GESIS Political Science Research Roundtable (Cologne, November 18, 2019) and wants to thank all participants for their valuable comments. This publication has benefited from a research stay of Carsten Wegscheider at GESIS-Leibniz Institute for the Social Sciences in November 2019 and was financially supported by GESIS research grant EL-2019-181. All mistakes remain ours. This research has received funding from the European Union's Horizon 2020 research and innovation program for the project "PaCE" under the grant agreement No 822337.

\section{Conflict of Interests}

The authors declare no conflict of interests. 


\section{Supplementary Material}

Supplementary material for this article is available online in the format provided by the authors (unedited).

\section{References}

Abts, K., \& Rummens, S. (2007). Populism versus democracy. Political Studies, 55(2), 405-424.

Adorno, T. W., Frenkel-Brunswik, E., Levinson, D. J., \& Sanford, N. (1950). The authoritarian personality. New York, NY: Harper \& Brothers.

Akkerman, A., Mudde, C., \& Zaslove, A. (2014). How populist are the people? Measuring populist attitudes in voters. Comparative Political Studies, 47(9), 1324-1353.

Altemeyer, B. (1981). Right-wing authoritarianism. Winnipeg: University of Manitoba Press.

Barr, R. R. (2009). Populists, outsiders and antiestablishment politics. Party Politics, 15(1), 29-48.

Bengtsson, Å. (2012). Citizens' perceptions of political processes. A critical evaluation of preference consistency and survey items. Revista Internacional de Sociología, 70(Extra 2), 45-64.

Bengtsson, Å., \& Christensen, H. (2016). Ideals and actions: Do citizens' patterns of political participation correspond to their conceptions of democracy? Government and Opposition, 51(2), 234-260.

Bengtsson, Å., \& Mattila, M. (2009). Direct democracy and its critics: Support for direct democracy and 'stealth' democracy in Finland. West European Politics, 32(5), 1031-1048.

Bosnjak, M., Dannwolf, T., Enderle, T., Schaurer, I., Struminskaya, B., Tanner, A., \& Weyandt, K. W. (2018). Establishing an open probability-based mixed-mode panel of the general population in Germany. Social Science Computer Review, 36(1), 103-115.

Bowler, S., Donovan, T., \& Karp, J. A. (2007). Enraged or engaged? Preferences for direct citizen participation in affluent democracies. Political Research Quarterly, 60(3), 351-362.

Canovan, M. (1999). Trust the people! Populism and the two faces of democracy. Political Studies, 47(1), 2-16.

Canovan, M. (2002). Taking politics to the people: Populism as the ideology of democracy. In Y. Mény \& Y. Surel (Eds.), Democracies and the populist challenge (pp. 25-44). London: Palgrave Macmillan.

Castanho Silva, B., Jungkunz, S., Helbling, M., \& Littvay, L. (2019). An empirical comparison of seven populist attitudes scales. Political Research Quarterly. https:// doi.org/10.1177/1065912919833176

Dalton, R. J. (2004). Democratic challenges, democratic choices: The erosion of political support in advanced industrial democracies. Oxford: Oxford University Press.

Duckitt, J., \& Bizumic, B. (2013). Multidimensionality of right-wing authoritarian attitudes: Authoritarianism- conservatism-traditionalism. Political Psychology, 34(6), 841-862.

Easton, D. (1965). A systems analysis of political life. New York, NY: John Wiley \& Sons.

Ennser-Jedenastik, L. (2016). A welfare state for whom? A group-based account of the Austrian Freedom Party's social policy profile. Swiss Political Science Review, 22(3), 409-427.

Font, J., Wojcieszak, M., \& Navarro, C. J. (2015). Participation, representation and expertise: Citizen preferences for political decision-making processes. Political Studies, 63(S1), 153-172.

Galston, W. A. (2018). The populist challenge to liberal democracy. Journal of Democracy, 29(2), 5-19.

GESIS. (2019). GESIS Panel-Standard edition. GESIS data archive, Cologne. ZA5665 Data file version 31.0.0 [Data set]. https://doi.org/10.4232/1.13320

Gherghina, S., \& Geissel, B. (2017). Linking democratic preferences and political participation: Evidence from Germany. Political Studies, 65(1_suppl), 24-42.

Hawkins, K. A., Carlin, R. E., Littvay, L., \& Rovira Kaltwasser, C. (Eds.). (2018). The ideational approach to populism: Concept, theory, and analysis. New York, NY: Routledge.

Heinisch, R. (2003). Success in opposition-Failure in government: Explaining the performance of right-wing populist parties in public office. West European Politics, 26(3), 91-130.

Heinisch, R., \& Wegscheider, C. (2019). Zum Verhältnis des Populismus zur liberalen Demokratie [On the relationship of populism to liberal democracy]. In M. Dürnberger (Ed.), Die Komplexität der Welt und die Sehnsucht nach Einfachheit [The complexity of the world and the longing for simplicity] (pp. 107-118). Innsbruck: Tyrolia.

Heinisch, R., \& Werner, A. (2019). Who do populist radical right parties stand for? Representative claims, claim acceptance and descriptive representation in the Austrian FPÖ and German AfD. Representation, 55(4), 475-492.

Hernández, E. (2018). Democratic discontent and support for mainstream and challenger parties: Democratic protest voting. European Union Politics, 19(3), 458-480.

Hibbing, J. R., \& Theiss-Morse, E. (2001). Process preferences and American politics: What the people want government to be. American Political Science Review, 95(1), 145-153.

Hobolt, S., Anduiza, E., Carkoglu, A., Lutz, G., \& Sauger, N. (2016). CSES module 5. Democracy divided? People, politicians and the politics of populism. (1 CSES Planning Committee Module 5 Final Report) Retrieved from https://cses.org/wp-content/uploads/2019/ 03/CSES5_ContentSubcommittee_FinalReport.pdf

Huber, R. A., \& Schimpf, C. H. (2016). A drunken guest in Europe? The influence of populist radical right parties on democratic quality. Zeitschrift Für Vergleichende Politikwissenschaft, 10(2), 103-129. 
Huber, R. A., \& Schimpf, C. H. (2017a). On the distinct effects of left-wing and right-wing populism on democratic quality. Politics and Governance, 5(4), 146.

Huber, R. A., \& Schimpf, C. H. (2017b). Populism and democracy: Theoretical and empirical considerations. In R. Heinisch, C. Holtz-Bacha, \& O. Mazzoleni (Eds.), Political populism: A handbook (pp. 329-344). BadenBaden: Nomos.

Kriesi, H. (2014). The populist challenge. West European Politics, 37(2), 361-378.

Landwehr, C., \& Steiner, N. D. (2017). Where democrats disagree: Citizens' normative conceptions of democracy. Political Studies, 65(4), 786-804.

Lefkofridi, Z., Wagner, M., \& Willmann, J. E. (2014). Leftauthoritarians and policy representation in Western Europe: Electoral choice across ideological dimensions. West European Politics, 37(1), 65-90.

Lubbers, M., Gijsberts, M., \& Scheepers, P. (2002). Extreme right-wing voting in Western Europe. European Journal of Political Research, 41(3), 345-378.

Mair, P. (2002). Populist democracy vs party democracy. In Y. Mény \& Y. Surel (Eds.), Democracies and the populist challenge (pp. 81-98). London: Palgrave Macmillan.

March, L. (2007). From vanguard of the proletariat to vox populi: Left-populism as a 'shadow' of contemporary socialism. SAIS Review of International Affair, 27(1), 63-77.

March, L. (2011). Radical left parties in contemporary Europe. New York, NY: Routledge.

March, L. (2017). Left and right populism compared: The British case. The British Journal of Politics and International Relations, 19(2), 282-303.

March, L., \& Mudde, C. (2005). What's left of the radical left? The European radical left after 1989: Decline and mutation. Comparative European Politics, 3(1), 23-49.

Mény, Y., \& Surel, Y. (2002). The constitutive ambiguity of populism. In Y. Mény \& Y. Surel (Eds.), Democracies and the populist challenge (pp. 1-21). London: Palgrave Macmillan.

Mohrenberg, S., Huber, R. A., \& Freyburg, T. (2019). Love at first sight? Populist attitudes and support for direct democracy. Party Politics, 1-12. https://doi.org/ $10.1177 / 1354068819868908$

Mudde, C. (2004). The populist Zeitgeist. Government and Opposition, 39(4), 541-563.

Mudde, C. (2007). Populist radical right parties in Europe. Cambridge: Cambridge University Press.

Mudde, C., \& Rovira Kaltwasser, C. (2012). Populism and (liberal) democracy: a framework for analysis. In C. Mudde \& C. Rovira Kaltwasser (Eds.), Populism in Europe and the Americas (pp. 1-26). Cambridge: Cambridge University Press.

Mudde, C., \& Rovira Kaltwasser, C. (2017). Populism: A very short introduction. New York, NY: Oxford University Press.

Neblo, M. A., Esterling, K. M., Kennedy, R. P., Lazer, D. M.
J., \& Sokhey, A. E. (2010). Who wants to deliberateAnd why? American Political Science Review, 104(3), 566-583.

Pappas, T. S. (2019). Populism and liberal democracy: $A$ comparative and theoretical analysis. Oxford: Oxford University Press.

Plattner, M. F. (2010). Populism, pluralism, and liberal democracy. Journal of Democracy, 21(1), 81-92.

Rooduijn, M. (2014). The nucleus of populism: In search of the lowest common denominator. Government and Opposition, 49(4), 573-599.

Rooduijn, M. (2018). What unites the voter bases of populist parties? Comparing the electorates of 15 populist parties. European Political Science Review, 10(3), 351-368.

Rooduijn, M., \& Akkerman, T. (2017). Flank attacks: Populism and left-right radicalism in Western Europe. Party Politics, 23(3), 193-204.

Rovira Kaltwasser, C. (2014). The responses of populism to Dahl's democratic dilemmas. Political Studies, 62(3), 470-487.

Rovira Kaltwasser, C., \& Van Hauwaert, S. M. (2020). The populist citizen: Empirical evidence from Europe and Latin America. European Political Science Review, 12(1), 1-18.

Rovny, J. (2013). Where do radical right parties stand? Position blurring in multidimensional competition. European Political Science Review, 5(1), 1-26.

Rydgren, J. (2007). The sociology of the radical right. Annual Review of Sociology, 33(1), 241-262.

Rydgren, J. (2018). The radical right: An introduction. In J. Rydgren (Ed.), The Oxford handbook of the radical right (pp. 1-14). New York, NY: Oxford University Press.

Schedler, A. (1996). Anti-political-establishment parties. Party Politics, 2(3), 291-312.

Schmitt-Beck, R., van Deth, J. W., \& Staudt, A. (2017). Die AfD nach der rechtspopulistischen Wende [The AfD after its right-wing populist turn]. Zeitschrift Für Politikwissenschaft, 27(3), 273-303.

Schumacher, G., \& Rooduijn, M. (2013). Sympathy for the 'devil'? Voting for populists in the 2006 and 2010 Dutch general elections. Electoral Studies, 32(1), 124-133.

Stanley, B. (2008). The thin ideology of populism. Journal of Political Ideologies, 13(1), 95-110.

Stark, T., Wegscheider, C., Brähler, E., \& Decker, O. (2017). Sind Rechtsextremisten sozial ausgegrenzt? Eine Analyse der sozialen Lage und Einstellungen zum Rechtsextremismus (Papers 2/2017). Berlin: RosaLuxemburg-Stiftung.

Stavrakakis, Y., \& Katsambekis, G. (2014). Left-wing populism in the European periphery: The case of SYRIZA. Journal of Political Ideologies, 19(2), 119-142.

Steiner, N. D., \& Landwehr, C. (2018). Populistische Demokratiekonzeptionen und die Wahl der AfD: Evidenz aus einer Panelstudie [Populist conceptions of democracy and voting for the Alternative for 
Germany: Evidence from a panel study]. Politische Vierteljahresschrift, 59(3), 463-491.

Stoker, G., \& Hay, C. (2017). Understanding and challenging populist negativity towards politics: The perspectives of British citizens. Political Studies, 65(1), 4-23.

Taggart, P. (2000). Populism. Buckingham: Open University Press.

Taggart, P. (2002). Populism and the pathology of representative politics. In Y. Mény \& Y. Surel (Eds.), Democracies and the populist challenge (pp. 62-80). London: Palgrave Macmillan.

Taggart, P. (2004). Populism and representative politics in contemporary Europe. Journal of Political Ideologies, 9(3), 269-288.

Urbinati, N. (1998). Democracy and populism. Constellations, 5(1), 110-124.

Urbinati, N. (2019). Political theory of populism. Annual Review of Political Science, 22(1), 111-127.

van Kessel, S. (2015). Populist parties in Europe: Agents of discontent? New York, NY: Palgrave Macmillan.

Vehrkamp, R., \& Wratil, C. (2017). A populist moment? Populist attitudes of voters and non-voters before the German federal election 2017. Gütersloh: Bertelsmann Stiftung.

Wagner, M., Aichholzer, J., Eberl, J.-M., Meyer, T. M., Berk, N., Büttner, N., ... Müller, W. C. (2018). AUTNES Online Panel Study 2017 (SUF edition) [Data set]. https://doi.org/10.11587/I7QIYJ

Webb, P. (2013). Who is willing to participate? Dissatisfied democrats, stealth democrats and populists in the United Kingdom. European Journal of Political Research, 52(6), 747-772.

Wuttke, A., Schimpf, C., \& Schoen, H. (2020). When the whole is greater than the sum of its parts: On the conceptualization and measurement of populist attitudes and other multidimensional constructs. American Political Science Review, 114(2), 356-374.

\section{About the Authors}

Reinhard Heinisch is Professor of Comparative Austrian Politics at the University of Salzburg. His main research is centered on comparative populism, Euroscepticism, political parties, and democracy. His research has appeared in journals such as the Journal of Common Market Studies, Party Politics, West European Politics, and Democratization. His latest book publication is The People and the Nation: Populism and Ethno-Territorial Politics (Routledge 2019).

Carsten Wegscheider is a PhD Fellow at the Department of Political Science at the University of Salzburg. His main area of research is comparative politics with an interest in democratization, political parties as well as political sociology and psychology. In his doctoral studies, he works on citizens' discontent with liberal democracy and support for radical populist parties from a comparative European perspective. 